\title{
AGE AT FIRST MARRIAGE IN EUROPE BEFORE 1850: A SUMMARY OF FAMILY RECONSTITUTION DATA
}

\author{
Katharine Gaskin*
}

\section{Introduction}

The development and application of family reconstitution methodology have recently invigorated historical demography. New findings from reconstitution studies continue to transform our knowledge of the behavior of populations in the past, enabling empirical evidence to revitalize the long-standing debates and assumptions of historical deomographers.

One of the most valuable products of family reconstitution is the knowledge it furnishes concerning the age at which populations married. Many interesting speculations have been generated by individual studies. As yet, however, no attempt has been made to pull together empirical findings from the bulk of these studies or to examine them longitudinally. This note remedies that situation. Here we summarize data from as many series of age at first marriage in Western Europe before 1850 as were available to us, drawn predominantly from reconstitutions and augmented by some genealogical material. The following review is by no means exhaustive, but it highlights the many substantive issues that can be explored using these data and presents a preliminary

* Katharine Gaskin is at present doing research at the Population Studies Center of the University of Michigan on international comparison of occupational differentiation by sex in this century.

The author would like to thank John Knodel who suggested the topic and helped with sources and comments, and Ron Lee who provided useful material. Thanks also to Bill Tehoy, Hallie Kintner, John Talbot, and Toni Richards. overview of trends in age at first marriage as they appear from these new empirical sources.

\section{Some Issues}

Age at marriage is a parameter of major strategic significance in preindustrial Western Europe. There is no need here to reiterate the economic, social, and demographic questions that have centered so much debate on the patterns and role of marrying age in European history (Hajnal, 1965; Krause, Razzell, McKeown, and Brown in Drake, 1969b; Habakkuk, 1953 and 1971; and Levine, 1974). A major issue here, however, is that many assumptions have been made concerning the behavior of this parameter, in particular that uniform changes took place in marriage age across all of Western Europe. Langer's essay on Europe's initial population explosion after the mideighteenth century summarizes this line of thought. Writing of late seventeenth and early eighteenth century Europe, Langer notes that

\footnotetext{
There appears to have been a distinct decline in the number of marriages and a rise in the age of marriage... But by the mideighteenth century the old regime was breaking down ... With the personal emancipation of the peasantry and the liquidation of the guild system, the common people were freer to marry, and evidently did so at an early age (Langer, 1968:9).
}

Langer's summary accords with many writers' assumptions concerning the rise and subsequent decline in marriage age in Europe between the seventeenth and 
nineteenth centuries. However, in a recent demonstration of the potential of reconstitution data, Smith's cross-sectional analysis of study results produces the suggestion of a "homeostatic pattern in demographic components among communities" (Smith, in press). According to the homeostasis argument, societies strive to maintain equilibrium; any disequilibrium tends to generate a correction or homeostatic response. Thus the rate of population growth in all populations will be more constant than the components of population change-mortality, marriage patterns, marital fertility, and migrationwhich combine and change differently within individual demographic regimes. Hence, acceptance of the homeostasis approach would lead one to expect little systematic variation in a parameter such as age at marriage across European communities. A similar kind of conclusion is suggested by the multiphasic response theory advanced by Davis (Davis, 1970:23-43). Another homeostatic argument, this points to the multiple demographic mechanisms used by populations suffering population pressure and suggests that different configurations of responses will occur under different conditions.

Such considerations underline the obvious, that preindustrial "Europe" was by no means a homogeneous area: there existed considerable variations both within and between countries. Specifically, such variants existed as earlier practice of birth control in France, German laws restricting marriage, and earlier industrialization in England. Each of these factors has been adduced as differentially affecting the marrying age. Particularly concerning the last factor, however, historians have noted that the apparent similarity of changes in fertility in Western Europe (and hence, it may be implied, in marriage age) make it difficult to invoke the immediate effects of industrialization and urbanization because they proceeded at such different paces in different areas (Tilly and Wrigley: chapter 1).

Morever, since Hajnal's identification of specifically European marriage patternsa phenomenon indicating a high degree of homogeneity in this area-one can validly consider Western Europe as a whole. If levels of marriage age in general are so similar, from Colyton to Crulai to Carl, then it is not unreasonable to look for similar trends and variations. As long as commentators assume the existence of uniform European trends, then the possibility deserves empirical investigation.

\section{The Data and Methodological Problems}

The data come from family reconstitution studies of communities in England, Flanders, France, Germany, Sweden, and Denmark. Data derived from German village genealogies provide a number of series, and data are included from genealogies on specific groups such as the aristocracy. In all, over forty studies provide data. Regretably, many of the pioneering French reconstitution studies do not provide series, but merely one age at marriage for the whole period observed (for example, Blayo, 1969; Ganiage, 1963; Dinet, 1969). We accept all published figures as correct. ${ }^{1}$

Methodological problems are quite severe, largely because of the variety of

${ }^{1}$ Two problems of bias in reconstitution data should be noted, however. Firstly, where marriage age is derived from linkage of marriage date to birth date, there exists a probability of bias towards a younger average age at marriage in the early years of the period studied; older women marrying in the period may have been born previous to it and records of their births would not be available. Hence their age at marriage cannot be calculated. Secondly, the issue of the representativeness of the reconstitutable minority is still being investigated. However, other findings (Smith, 1977; Levine, 1976; and Wrigley, 1977) suggest that extreme doubt concerning the representativeness of reconstitution studies is not warranted. 
approaches used by researchers in collating and presenting age at marriage data. The availablility of good records and the small numbers of useable cases in certain periods clearly constrained the compilers of the series. Given these drawbacks, there remains no consensus on how to present the data. Researchers employ different measures of central tendency $^{2}$ and different adjustment procedures. Sometimes the number of cases is not given. Length of series ranges from two to twenty items of data. Some studies present data by birth cohort, while others favor the marriage cohort approach. Since the latter makes more substantive sense, all data have been adjusted to provide series of marriage age by year of marriage. ${ }^{3}$

The wide variety of ways in which any given time period is divided by different researchers presents an additional problem. Cut-off points seem to be determined at times by the writer's expectation of divisions that would best illustrate changes in marriage age, at times by the desire for more equal distribution of cases, and at times for no obvious reason. ${ }^{4}$. In order to maximize comparability, average ages of

2This analysis uses means only, the most common measure. Of course, changes in distribution about the mean are not captured, and highly skewed distributions may disproportionately influence mean values. Future reconstituters are advised to consider calculating medians and quartiles, as well as means.

${ }^{3}$ Twenty-five years was added to the dates where marriage ages were given by birth year. Marriage age data for a cohort born between, say, 1700 and 1724 thereby became data for a marriage cohort marrying between 1725 and 1749 .

${ }^{4}$ For example, data for the eighteenth century were presented by decade for Tamerville and Göttelfingen, by fifty-year periods for Tiefenbach, by twenty-year periods for Moreton Say, by alternating twenty- and thirty-year periods for Colyton and in three unequal periods $(1700-39,1740-66,1767-92)$ for Thézels-Saint-Sernin, to name but a few of the variations. marriage have been calculated for fifty-year periods, and trends examined in terms of changes between the two halves of a century. ${ }^{\mathrm{s}}$

The fullest data exist for the period 1700 to 1850 , although all data obtained have been used. Only three of the more detailed series include figures prior to $1600 .{ }^{6}$ Few data appear for the seventeenth century; to augment material obtained from the series. We have included data for seven English parishes which give mean female age at marriage only for periods 1600-1649 and 1650-1699 (Levine and Wrightson, 1976:4), For later dates, the analysis uses one or two figures of female age at marriage without male equivalents. The text or tables indicate where N's differ. ${ }^{?}$

${ }^{5}$ Fifty-year averages could not always be derived. In some cases averages were approximations extending prior to or beyond the strict half-century limits, but those retained in the analysis were adjudged to be adequate representations of a period in general. Some good series, such as El Kordi's Bayeux data, had to be excluded because numbers of cases were not provided and thus recalculation of longer-term means was unreliable.

'These are Colyton, Genevan Bourgeoisie, and British Peerage. The last two, as Hajnal suggested, indicate that marriage age may have developed its European level sometime in the sixteenth century amongst upper class groups; the figure for Peller's European ruling families for the whole sixteenth century indicates a similar conclusion. The two German family genealogies studied by Rumelin-which give figures only by century-show female marriage age declining from the sixteenth to the seventeenth century, although in one family there are few cases for the sixteenth century, and in the second the decline is quite small. In the latter case, the ages are "subEuropean" up to the eighteenth century. Male marriage age rose steadily through four centuries, and particularly after the seventeenth, a pattern also discernible among the women. Colyton's female and male ages at marriage were already very high in the period 1560-99 (27.0 and 28.1); the female remained unchanged through mid-seventeenth century, while the male declined by about a year.

'The cases for each half-century for female age 
We show trends by hundred-year periods, indicating the direction and amount of change in the age at marriage between the two half-centuries. Some cases appear where the means do not adequately represent fifty-year periods, and thus one could not calculate the amount of change during the century in number of years. However, where it is fairly clear that the age at marriage tended to change in one direction during the period, this is indicated by the appropriate sign $(-$ or + ) followed by an asterisk. Thus there may be more cases of directional change than of numerical change. ${ }^{8}$

\section{Results}

The left hand side of table 1 shows the direction and magnitude of change in age at first marriage for women and men by hundred-year periods. Data available for women only are listed below those for both sexes. This part of table 1 should be read in conjunction with table 2 . The mean

\footnotetext{
${ }^{\top}$ (continued)

at marriage are: $1600-49,12 ; 1650-99,19 ; 1700-49$, $23 ; 1750-99,23 ; 1800-49,19$. Both male and female data are available for the following number of cases, by period order: $5,12,23,22,17$.
}

${ }^{8}$ Total numbers of cases for which numerical change could be calculated for both women and men are: $1600-49 / 1650-99,5 ; 1650-99 / 1700-49,12$; 1700-49/1750-99, 20; 1750-99/1800-49, 16. Inclusion of cases where direction only is indicated, for both men and women, adds two cases to the second period and four to the third. In this latter period, three further cases are included for direction of female change only; male data existed but were not susceptible to estimation of either amount or direction of change. There are two instances of this added into the final period.

A few studies provided data that could not be fitted into the analysis, even given the flexibility of the asterisk, because their time divisions were too large or ambiguous. The Genevan Bourgeoisie, for example, had marriage year time periods of fifty years starting at -25 and -75 . Eversele, Flanders, and Peller's European ruling families are two further examples. Examination of this small sample of unuseable data series reveals no sign of any common trend. changes in age at first marriage shown in table 2 are derived by aggregating and averaging the individual amounts of change in the third and fourth columns of table 1 .

First, apparently no conclusions can be drawn for the seventeenth century. The data relate primarily to England and to women, and indicate a predominantly rising age at marriage. Table 2 shows an average rise of .18 years for all females for this period.

Change in marriage age between the second half of the seventeenth and first half of the eighteenth century is clearly in an upward direction for women; an average rise of almost one year takes place, indicating a significantly later timing of marriage in the sample after 1700 than before. The picture is more mixed for the men, however. An average decline of nearly one third of a year, as shown in table 2, obscures the fact that half of the men in the sample marry later and half earlier than in the previous half-century. Thus, while no trend is discernible among the males, one can speak of a definite tendency for women to marry later after 1700 than in earlier cohorts.

The pattern visible in the eighteenth century partially confirms a trend towards earlier female marriage; almost two thirds of the women marry at a younger age by the end of this period. On the average, the female marriage age drops by a little more than half a year during the eighteenth century. In a number of places across Europe, however, the women continue to marry later than did those in the earlier cohorts from 1700 to 1749 . The same is true for a large minority of the men, who as a group do not show the same tendency towards earlier marriage as the women. By individual cases, about half marry later, half earlier, and a few stay the same; on the average, essentially no change appears in the male marriage age.

The same is broadly true of the men in 
TABLE 1. CHANGE IN AGE AT FIRST MARRIAGE, FEMALE AND MALE, BY 100 YEAR PERIODS, SHOWING AMOUNT OF CHANGE AND COMPARING DIRECTION AND MAGNITUDE OF CHANGE BY SEX*

\begin{tabular}{|c|c|c|c|c|c|c|c|}
\hline \multirow[b]{2}{*}{ Place or Group } & \multirow[b]{2}{*}{ Country** } & \multicolumn{2}{|c|}{ Change } & \multicolumn{4}{|c|}{ Change in Same Direction } \\
\hline & & Female & Male & Yes & No & $\geq 1$ & $<1$ \\
\hline \multicolumn{8}{|c|}{ Period 1600-1649/1650-1699 } \\
\hline Colyton & E & +2.3 & +.3 & $x$ & & & \\
\hline Bottesford & $\mathbf{E}$ & +.7 & -1.6 & & $\mathrm{x}$ & & \\
\hline Finkenwärder & $\mathrm{G}$ & -.3 & +.1 & & $\mathrm{x}$ & & \\
\hline Tiefenbach & $\mathrm{G}$ & -3.3 & -.8 & $\mathrm{x}$ & & & \\
\hline Giessen & $\mathrm{G}$ & -.7 & -1.1 & $x$ & & & \\
\hline Alcester & $\mathbf{E}$ & +1.4 & & & & & \\
\hline Aldenham & E & +.9 & & & & & \\
\hline Banbury & $\mathrm{E}$ & +1.3 & & & & & \\
\hline Hartland & E & +.6 & & & & & \\
\hline Hawkshead & $\mathrm{E}$ & +1.7 & & & & & \\
\hline Shepshed & $\mathrm{E}$ & -1.5 & & & & & \\
\hline Terling & $\mathrm{E}$ & -1.0 & & & & & \\
\hline \multicolumn{8}{|c|}{ Period 1650-1699/1700-1749 } \\
\hline Bottesford & $\mathrm{E}$ & +1.0 & +1.1 & $x$ & & $\mathrm{x}$ & \\
\hline British Peerage & $\mathbf{E}$ & $+*$ & $+*$ & $\mathrm{x}$ & & & \\
\hline Tamerville & F & +2.4 & +.8 & $x$ & & & \\
\hline Tourouvre & $\mathrm{F}$ & +1.5 & -.4 & & $\mathrm{x}$ & & \\
\hline Meulan & $\mathrm{F}$ & $+*$ & $+*$ & $\mathrm{x}$ & & & \\
\hline Bléré & $\mathrm{F}$ & +.2 & -2.3 & & $\mathrm{x}$ & & \\
\hline Böhringen & G & +.7 & +.3 & $x$ & & & $\mathrm{x}$ \\
\hline Göttelfingen & $\mathrm{G}$ & +2.2 & +1.0 & $\mathrm{x}$ & & $\mathrm{x}$ & \\
\hline Winsen & $\mathbf{G}$ & +.9 & -2.6 & & $\mathrm{x}$ & & \\
\hline Tiefenbach & $\mathbf{G}$ & +3.8 & +1.8 & $x$ & & $\mathrm{x}$ & \\
\hline Colyton & $\mathbf{E}$ & -1.0 & -.3 & $\mathrm{x}$ & & & \\
\hline Ducs et Pairs & $\mathbf{F}$ & -.6 & -1.9 & $x$ & & & \\
\hline Finkenwärder & G & -.1 & -.3 & $x$ & & & $\mathbf{x}$ \\
\hline Giessen & $\mathbf{G}$ & -.1 & -.7 & $\mathrm{x}$ & & & $x$ \\
\hline Shepshed & $\mathrm{E}$ & +.1 & & & & & \\
\hline \multicolumn{8}{|c|}{ Period 1700-1749/1750-1799 } \\
\hline British Peerage & $\mathrm{E}$ & +1.8 & N.C. ${ }^{* * *}$ & & $x$ & & \\
\hline Moreton Say & $E$ & +.2 & +.5 & $\mathrm{x}$ & & & $\mathbf{x}$ \\
\hline Adegem & Fl & +1.4 & +.3 & $\mathrm{x}$ & & & \\
\hline Boulay & F & +2.7 & +2.7 & $\mathrm{x}$ & & $\mathrm{x}$ & \\
\hline Thézels & F & $+*$ & $\ldots * * * *$ & & & & \\
\hline Bléré & $\mathbf{F}$ & $+*$ & $+*$ & $x$ & & & \\
\hline Böhringen & G & +1.3 & N.C.*** & & $x$ & & \\
\hline Winsen & $\mathbf{G}$ & +.4 & +1.1 & $x$ & & & \\
\hline Anhausen & G & +.4 & +1.9 & $\mathrm{x}$ & & & \\
\hline Rendalen & $N$ & $+*$ & $+*$ & $\mathrm{x}$ & & & \\
\hline
\end{tabular}

the final period, 1750 to 1850 ; a more or less equal tendency exists for later and for earlier marriage, averaging to a minimal decline. In this period, too, there is no distinguishable pattern among the women, with roughly half marrying later and half earlier. On the average, female marrying age rises by about a third of a year, a high figure partly caused by large rises in some of the German communities.

Table 3 shows mean ages at marriage calculated for each fifty-year period over the whole sample. One should bear in mind the fact that the sample for each period is differently composed; one is not dealing with ages at marriage in the same 
TABLE 1. CHANGE IN AGE AT FIRST MARRIAGE, FEMALE AND MALE, BY 100 YEAR PERIODS, SHOWING AMOUNT OF CHANGE AND COMPARING DIRECTION AND MAGNITUDE OF CHANGE BY SEX* (continued)

\begin{tabular}{|c|c|c|c|c|c|c|c|}
\hline \multirow{2}{*}{ Place or Group } & \multirow[b]{2}{*}{ Country** } & \multicolumn{2}{|c|}{ Change } & \multicolumn{4}{|c|}{ Change in Same Direction } \\
\hline & & Female & Male & Yes & No & $>1$ & $\leq 1$ \\
\hline \multicolumn{8}{|c|}{ Period 1700-1749/1750-1799 } \\
\hline Colyton & $\mathbf{E}$ & -1.9 & N.C.*** & & $\mathrm{x}$ & & \\
\hline Bottesford & $\mathbf{E}$ & -.9 & +.2 & & $x$ & & \\
\hline Shepshed & E & -2.3 & -2.9 & $\mathrm{x}$ & & $\mathbf{x}$ & \\
\hline Glostrup & $\mathrm{D}$ & $\ldots *$ & $-*$ & $\mathrm{x}$ & & & \\
\hline Le Vieuxbourg & $\mathrm{Fl}$ & -.3 & +.7 & & $\mathbf{x}$ & & \\
\hline 4 Villages & $\mathrm{Fl}$ & -1.3 & -1.1 & $\mathbf{x}$ & & $\mathrm{x}$ & \\
\hline Ducs et Pairs & $\mathrm{F}$ & -1.1 & -2.3 & $\mathrm{x}$ & & $\mathrm{x}$ & \\
\hline Tamerville & $\mathrm{F}$ & -.6 & N.C. $* * *$ & & $\mathbf{x}$ & & \\
\hline Meulan & $\mathrm{F}$ & $-*$ & $-\_-* * * *$ & & & & \\
\hline Bilhères & $\mathrm{F}$ & - $*$ & $\ldots \ldots * * *$ & & & & \\
\hline Sainghin & $\mathrm{F}$ & -.9 & -.8 & $x$ & & & $\mathbf{x}$ \\
\hline St. Vigor & $F$ & -2.5 & -.5 & $\mathrm{x}$ & & & \\
\hline Tiefenbach & G & -3.0 & +.9 & & $\mathrm{x}$ & & \\
\hline Göttelfingen & $\mathrm{G}$ & -1.4 & -.2 & $\mathrm{x}$ & & & \\
\hline Finkenwärder & G & -.7 & +.2 & & $x$ & & \\
\hline Heuchelheim & G & -2.1 & -.8 & $\mathrm{x}$ & & & \\
\hline Durlach & $\mathrm{G}$ & $-*$ & $-*$ & $\mathrm{x}$ & & 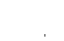 & . \\
\hline \multicolumn{8}{|c|}{ Period $1750-1799 / 1800-1849$} \\
\hline British Peerage & $\mathrm{E}$ & +.7 & +1.9 & $\mathbf{x}$ & & & \\
\hline Moreton Say & $\mathrm{E}$ & +.6 & +.5 & $\mathrm{x}$ & & & $\mathrm{x}$ \\
\hline Boulay & $\mathrm{F}$ & +.8 & N.C.*** & & $\mathbf{x}$ & & \\
\hline Finkenwärder & $\mathrm{G}$ & +.2 & -.4 & & $\mathrm{x}$ & & \\
\hline Göttelfingen & G & +1.5 & +.2 & $x$ & & & \\
\hline Frommern & $G$ & +2.6 & +2.4 & $x$ & & $\mathrm{x}$ & . \\
\hline Carl & G & +3.1 & +1.5 & $\mathrm{x}$ & & $\mathrm{x}$ & \\
\hline Anhausen & G & +2.4 & +1.0 & $x$ & & $\mathrm{x}$ & \\
\hline Heuchelheim & $\mathrm{G}$ & +.3 & -.3 & & $\mathrm{x}$ & & \\
\hline Colyton & $\mathrm{E}$ & -2.2 & -1.2 & $x$ & & $x$ & \\
\hline Shepshed & $\mathrm{E}$ & -1.6 & -1.3 & $\mathbf{x}$ & & $\mathrm{x}$ & \\
\hline Bottesford & $\mathrm{E}$ & -1.6 & -2.6 & $\mathrm{x}$ & & $\mathrm{x}$ & \\
\hline Meulan & $\mathrm{F}$ & - * & ___ $* * * * *$ & & & & \\
\hline Bilhères & $\mathrm{F}$ & _ * & $\ldots \ldots * * *$ & & & & \\
\hline Sainghin & $\mathrm{F}$ & -.5 & -2.4 & $\mathrm{x}$ & & & \\
\hline Tiefenbach & $\mathrm{G}$ & -1.1 & -1.4 & $\mathrm{x}$ & & $x$ & \\
\hline Böhringen & G & -.1 & +.7 & & $\mathbf{x}$ & & \\
\hline Winsen & $G$ & -.3 & +.6 & & $x$ & & \\
\hline Adegem & $\mathrm{Fl}$ & +.6 & & & & & \\
\hline Alskog & $\$$ & $+*$ & & & & & \\
\hline
\end{tabular}

* An asterisk appears where time periods are such that amount of change cannot bc reliably calculated, but direction of change is reasonably ascertainable. For example, Bilheres' periods are 1740 $1749,1780-1819,1820-1859$, and the female marrying ages by period are $27.1,25.6,24.9$, a fairly obvious decline through the whole time span.

**Country code: E-England; F-France; Fl-Flanders; G-Germany; D-Denmark; N-Norway; SSweden. Places are listed pre-eminently by change in female age at marriage; increases are grouped first, then declines, with the same pattern maintained among only female data Within this structure, places are grouped by country.

$* * *$ No change.

****Data are available, but neither amount of change nor direction can be estimated with any certainty. 
TABLE 2. MEAN CHANGE IN AGE AT FIRST MARRIAGE BY 100-YEAR PERIODS WITH CORRELATIONS BETWEEN FEMALE AND MALE CHANGES*

\begin{tabular}{|c|c|c|c|c|c|c|}
\hline \multirow[b]{2}{*}{ Period } & \multicolumn{4}{|c|}{ Series with Female and Male Data } & \multicolumn{2}{|c|}{ All Female Data } \\
\hline & Female & Male & I & $(\mathrm{N})$ & Female & $(\mathrm{N})$ \\
\hline $1600-1649 / 1650-1699$ & -.26 & -.62 & .32 & $(5)$ & +.18 & $(12)$ \\
\hline $1650-1699 / 1700-1749$ & +.91 & -.29 & .64 & $(12)$ & +.85 & (13) \\
\hline $1700-1749 / 1750-1799$ & -.54 & -.005 & .55 & $(20)$ & -.54 & $(20)$ \\
\hline $1750-1799 / 1800-1849$ & +.30 & -.05 & .79 & (16) & +.32 & $(17)$ \\
\hline
\end{tabular}

*The correlation coefficient calculated is Pearson's $r$.

TABLE 3. MEAN AGE AT FIRST MARRIAGE BY 50-YEAR PERIODS WITH MEAN DIFFERENCE BETWEEN FEMALE AND MALE AGES AND STANDARD DEVIATIONS IN PARENTHESES

\begin{tabular}{|c|c|c|c|c|c|c|}
\hline \multirow[b]{2}{*}{ Period } & \multicolumn{4}{|c|}{ Series with Female and Male Data } & \multicolumn{2}{|c|}{ All Female Data } \\
\hline & Female & Male & Diff* & $(\mathrm{N})$ & Female & $(\mathrm{N})$ \\
\hline $1600-1649$ & $\begin{array}{c}26.6 \\
(2.08)\end{array}$ & $\begin{array}{c}28.5 \\
(1.23)\end{array}$ & $\begin{array}{c}1.8 \\
(1.60)\end{array}$ & ( 5) & $\begin{array}{c}26.2 \\
(1.85)\end{array}$ & $(12)$ \\
\hline $1650-1699$ & $\begin{array}{c}24.4 \\
(2.38)\end{array}$ & $\begin{array}{c}27.7 \\
(1.33)\end{array}$ & $\begin{array}{c}3.4 \\
(2.08)\end{array}$ & (12) & $\begin{array}{c}25.1 \\
(2.32)\end{array}$ & (19) \\
\hline $1700-1749$ & $\begin{array}{c}25.5 \\
(2.62)\end{array}$ & $\begin{array}{c}27.6 \\
(2.05)\end{array}$ & $\begin{array}{c}2.1 \\
(2.86)\end{array}$ & (23) & $\begin{array}{c}25.5 \\
(2.62)\end{array}$ & $(23)$ \\
\hline $1750-1799$ & $\begin{array}{c}25.1 \\
(2.07)\end{array}$ & $\begin{array}{c}27.8 \\
(2.27)\end{array}$ & $\begin{array}{c}2.8 \\
(1.58)\end{array}$ & (22) & $\begin{array}{c}25.0 \\
(2.03)\end{array}$ & $(23)$ \\
\hline $1800-1849$ & $\begin{array}{c}25.7 \\
(2.00)\end{array}$ & $\begin{array}{c}28.1 \\
(2.16)\end{array}$ & $\begin{array}{c}2.4 \\
(1.62)\end{array}$ & (17) & $\begin{array}{c}25.7 \\
(1.90)\end{array}$ & (19) \\
\hline
\end{tabular}

*Difference in years, calculated by summing individual differences; the discrepancies between this figure and the difference between male and female period means is caused by rounding error.

places over time. Therefore one must be careful in interpreting this table. The table does show, however, a pattern of changes of marriage age similar to the one which has already emerged, especially for the women. There is a marked tendency toward later marriage after 1700. This trend is then reversed, as women in the second part of the eighteenth century marry younger, while the women marrying after 1800 again appear to be postponing marriage more than the cohorts marrying in the previous fifty years.

As for the men, the apparent constancy of their average marriage age for two hundred years after 1650 is a striking feature of table 3 , although the parenthesized standard deviations indicate increasing dispersion about the mean in the final hundred years. While the differences involve mere fractions of a year, the men seem to have married at their youngest between 1700 and 1749 , with later marriage gradually occurring through mid-nineteenth century. The nature of the compilation of this table, however, calls for caution in speaking of trends. The table seems to confirm, rather, the earlier discovery of no clear trends in male marriage age during this period.

The finding that the male age at marriage held so steady over two centuries recalls a conclusion drawn by Wrigley from his Colyton data and an assumption implicitly made by several other writers, 
namely that male marriage age changed much less over time than the female age, which was subject to a high degree of fluctuation. ${ }^{9}$ In general, the detailed series collected for the analysis do not substantiate this finding; in addition, table 1 shows that in just under half of the measurable incidences, male age changes as much as or more than female age. Thus, the impression given by tables 2 and 3 of a high degree of stasis in male marriage age with marked fluctuations in the female age is not necessarily correct, especially in view of the fact that the apparently negligible changes after 1700 result from equal tendencies towards both earlier and later marriage by the men. Thus, while individual places or groups may experience greater fluctuation in the women's marriage age, in general these data indicate that one cannot speak with confidence of a highly stable male age at marriage in European history.

Another issue that we can examine with the data assembled here concerns the extent to which women and men in the sample both tended to enter marriage later or earlier. In other words, the degree of synchronization of changes in marriage age between the sexes. Most factors hypothesized as having had an impact on marriage age would logically affect both women and men. In particular, the theory of the impact of industrialization on

${ }^{9}$ Also Wrigley, 1977. Received too late to incorporate in this analysis, the paper demonstrates in Wrigley's view a clear trend in female marriage age in ten English parishes; marriage age rose in the seventeenth century to peak late in that century or early in the eighteenth, falling continuously thereafter to lower levels in the early nineteenth century. Overall, then, our findings for women tally with Wrigley's, except for the final period. Noting the "comparatively slight" changes in male age, he identifies, however, an echo of female changes among the men too, though any trends are much less clearcut. Wrigley's paper contains many interesting items, illustrating the wealth of information that can be derived from skilfully utilized reconstitution data. See, in addition, footnotes 1,10 , and 11 . fertility via lowered age at marriage requires a high correlation between changes in both sexes' marrying age. One assumes that economic changes encouraging earlier marriage first affect men who proceed to marry younger women, whose exposure to youthful childbearing thereby increases. Citing such expectations, Drake finds it "disconcerting . . . that the ages at marriage of the men and women do not move in step" in his data for England and Norway (Drake, 1969:200). ${ }^{10}$

Our results indicate a moderately high degree of correspondence between female and male changes in marriage age. Table 1 shows that male and female change can be compared in fifty-nine cases altogether. Forty-one of these, close to 70 percent, show a similar direction of change for women and men. Of the remaining thirteen cases, male age changes differently from female, and in a further five female age rises or falls while the male remains unchanged.

We considered the possibility that female and male marriage age behavior became more similar as time wore on and the concerted effects of such large-scale processes as industrialization (or perhaps proto-industrialization) produced greater correspondence between male and female trends. The third column of table 2 indicated the extent of correlation (Pearson's r) between female and male changes within each hundred-year period. Clearly, correlations after 1650 are moderately high, but do not increase systematically over time. The correlation of .79 between 1750 and 1850 , however, is the highest and suggests a fairly close correspondence of female and male

${ }^{10}$ Wrigley, 1977, does not mention this issue and does not seem disconcerted that close to half of the changes in female marriage age in the ten parishes between 1550 and 1849 are not accompanied by corresponding changes in the men's age of entering marriage. 
marriage age trends in this most recent period.

The final four columns of table 1 enable one to examine the components of the correlations presented in table 2 . These columns show whether or not male and female ages change in the same direction; and if they do, whether the changes are of roughly the same magnitude-either greater than a year, or less. In the periods $1650-1750$ and 1750-1850, one half of the measurable changes occur both in the same direction and in the same degree, while in the eighteenth century less than a third do. In terms of direction alone, nearly four-fifths of the cases match in direction in the 1650-1750 period, while around twothirds match in both later periods. These findings confirm that correspondence does not increase over time and that usually male and female ages at marriage do move in step, although the actual amount of change is less synchronized between the sexes.

Table 3 indicates two more results of collating and summarizing family reconstitution data. Beneath the mean ages are presented standard deviations which, in default of more detailed information concerning distribution about the mean, give some impression of the extent of dispersion. ${ }^{13}$ Apparently, the variability in women's ages at marriage tends to decrease over time, while the men show something of a counter tendency.

Table 3 also includes for each period the average difference between female and male marrying ages, calculated in view of recent work of the effect on fertility of an older male marrying age and large

"Wrigley, 1977, demonstrates the value of calculating quartiles and medians to get at the important matter of varying dispersion about the mean. Interestingly, his findings of increasing compression of women's marriage ages into a shorter span over time, while the men's ages appear to become more variable, tally with our limited conclusions on the basis of standard deviations. differences between the sexes in age at marriage (Anderson, 1975:561-567; Herlihy, 1977). We see, first, that the average difference of two to three years accords well with other estimates of this figure for Western Europe. With occasional exceptions the vast majority of our data exhibit an older male than female marriage age. Clearly, after 1700 the age difference varies only moderately; and it is rather unlikely that the variation could account for any independent effect on fertility. The greatest age gap, 3.4 years, occurs in the second half of the seventeenth century; and this decreases by over a year in the following period. The period from 1700-49 has the smallest average age gap occurring after 1650 , but also the highest degree of dispersion. The spread about the mean appears to diminish considerably after 1750 , although it remains relatively high, apparently indicating little uniformity across the sample as to differences between female and male marriage ages.

\section{Summary and Discussion}

Our findings suggest that historical demographers can learn much from collating and analyzing family reconstitution results. Though our conclusions remain incomplete and tentative, we are encouraged to find that some confirm findings elsewhere. We are also stimulated by the fact that some results challenge existing ideas and hypotheses. The major issue of trends in marriage ages between 1650 and 1800 is a prime example. We found women in this sample did tend to marry later in the first part of the eighteenth century than did those from cohorts in the previous fifty years. In addition, the majority of cohorts marrying between 1750 and 1800 experienced earlier marriage than their mothers and grandmothers. Thus we have some confirmation of commonly assumed trends. 
On the other hand, findings for the final hundred years and for men are not straightforward. No clear trend appears for women between 1750 and 1850. A more or less equal tendency exists towards earlier and later marriage; and if anything, the aggregate tendency points towards a rising marriage age. Breakdowns by country are no more clearcut, although this may change with the availability of more cases per country. In addition, these findings cannot corroborate any assumptions of trends in the male marriage age throughout the time period covered. Actually, the most striking fact is that in almost equal proportions, the samples of men entered marriage both earlier and later than their predecessors. In view, therefore, of the somewhat more distinct trends discovered among women, we find a less than perfect correspondence between female and male changes in marriage age. The highest correlation occurs in the final hundred years, with no detectable female trends. This leads one to the conclusion that whatever factors $d i d$ produce changes in marrying age in this most recent period, they acted more concertedly on both sexes than in former times. In this later period, there also emerges a relatively low variability in the age difference between spouses, possibly indicating increasing uniformity in this aspect of marriage behavior.

Our finding of no trends in male age at marriage suggests a need to review arguments which link social and economic changes to population growth through their effect on the male marrying age and hence on the female marrying age. If future work confirms the results of this analysis, then it seems we must reconsider the process through which industrialization and modernization have been thought to affect population growth. On the other hand, the trends we identified among European women are hardly overwhelming, and conclusions rest on a relatively small number of cases. We look forward to fuller investigation of these issues.

Nevertheless, one can see why these results are interesting. One cannot entirely reject traditional assumptions about historical trends, yet some of the implicit components of these assumptions receive no validation here. For example, our findings partially suggest the homeostasis argument; and yet we detect some degree of conformity of behavior among very diverse women throughout Western Europe. Perhaps we should not expect one extreme or the other in terms of neat equivalence to theory, but a combination of the two processes. In other words, the homeostatic pattern generally obtained, but certain major economic and social processes were capable of effecting ineluctable demographic consequences wherever they occurred. Thus the appearance of trends could be superimposed on a situation of intrinsic variety. But then one must wonder how such processes influenced female marriage behavior without apparently having the same effect on the male.

The results of this study are limited and tentative, producing more questions than answers. Such an analysis could not, however, have been conducted even a few years ago. This incomplete review indicates the wealth of material being produced by the family reconstitution method and the number of substantive implications that can be derived from such data. At this point, a review of age at marriage data largely demonstrates that historical demographers have a great deal to discover about changes in marriage age in Europe, about the interrelationships between female and male marriage ages, and about the factors that determined and changed these parameters in pre-industrial populations. This imperfect but promising beginning will surely yield to more comprehensive and dependable analyses in the future. Reconstitution data may 
ultimately help resolve the many debates and questions of historical demographers concerning the behavior of the women and men of pre-industrial Europe.

\section{BIBLIOGRAPHY}

Anderson, Barbara A.

1975 "Male Age and Fertility Results from Ireland prior to 1911," Population Index, 4: 561-7.

Blayo, Yves

1969 "Trois Paroisses d'llle-et-Vilaine." Annales de Démographie Historique: 191-213.

Davis, Kingsley

1970 "The Theory of Change and Response in Modern Demographic History." In R. Ford and G. deJong, eds., Social Demography, 23-43. New Jersey.

Dinet, Dominique

1969 "Quatre Paroisses du Tonnerrois." Annales de Démographie Historique: 62-85.

Drake, Michael

1969a "Age at Marriage in the Pre-Industrial West." In F. Bechhofer, ed., Population Growth and the Brain Drain, 196-207.

$1969 \mathrm{~b}$ Ed., Population in Industrialization. London.

Ganiage, $\mathbf{J}$.

1963 Trois Villages de L'Ile de France du XVII siècle: Etude Demographique. Paris.

Habakkuk, H. J.

1953 "English Population in the Eighteenth Century." Economic History Review, second series, 6:117.133.

1971 Population Growth and Economic Development since 1750. Leicester.

Hajnal, J.

1965 "European marriage patterns in perspective." In Glass, D. V. and D. E. C. Eversley, eds., Population in History, London, 1965: 101-143.
Herlihy, D.

1977 "Deaths, Marriages, Births and the Tuscan Economy, ca. 1300-1550." In Ronald D. Lee, ed., Population Patterns in the Past. Academic Press, in press.

Krause, J.T., P.E. Razzell, T. McKeown and R.G. Brown.

1969 In M. Drake, ed. Population in Industrialization. London.

Langer, William L.

1968 "Europe's Initial Population Explosion." In D. M. Heer, ed., Readings on Population, 2-15. New Jersey.

Lee, Ronald Demos, ed.

1977 Population Patterns in the Past. Academic Press, in press.

Levine, David $C$.

1974 "The Demographic Implications of Rura1 Industrialisation: A Family Reconstitution Study of Two Leicestershire Villages, 1600 1851." Unpublished Ph.D. Dissertation, University of Cambridge.

1976 "The Reliability of Parochial Registration and the Representativeness of Family Reconstitution." Population Studies, 1:107. 122.

Levine, David C. and $\mathrm{K}$. Wrightson

1976a "The Social Context of Illegitimacy in Early Modern England." Unpublished paper: 4.

Smith, Daniel Scott

1977 "A Homeostatic Demographic Regime: Patterns in West European Family Reconstitution Studies." In Ronald D. Lee, ed., Population Patterns in the Past. Academic Press, in press.

Tilly, Charles \& Wrigley, E. A., eds. Historical Studies of Changing Fertility. Princeton University Press, forthcoming.

Wrigley, E. A.

1977 "Age at Marriage in early modern England." Unpublished paper. 


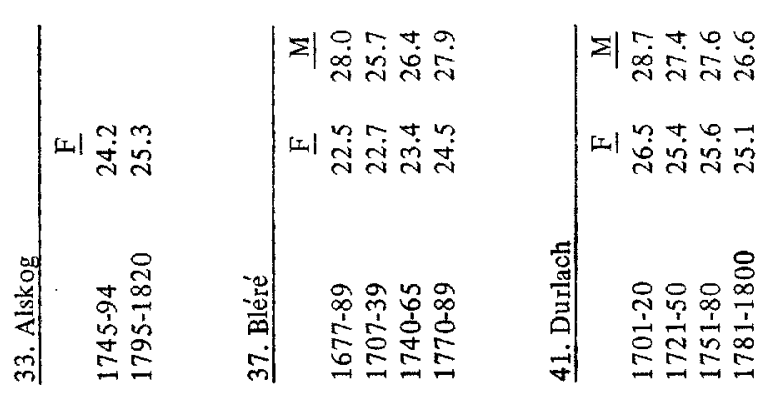

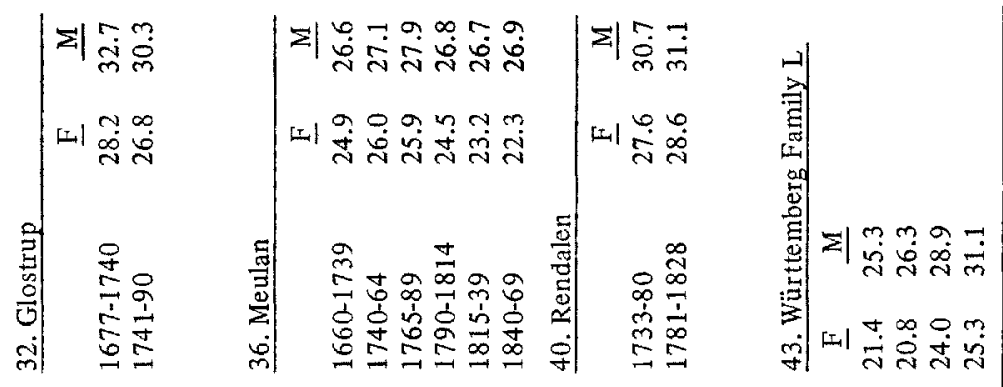

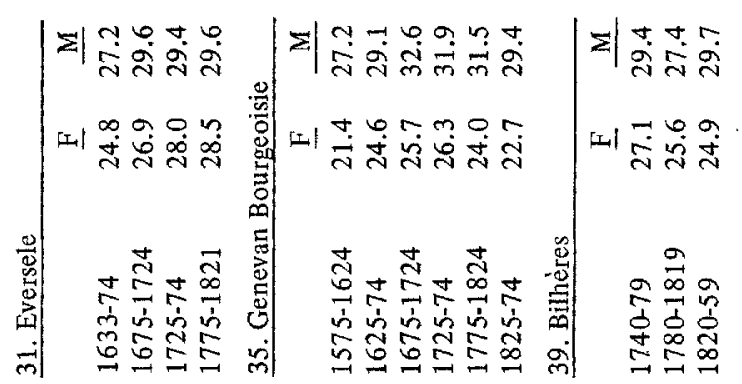

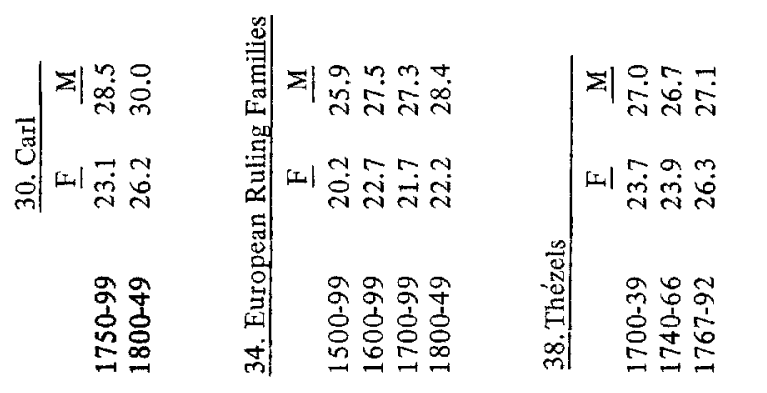

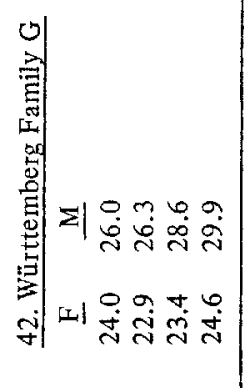

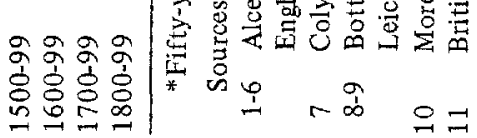




\section{JOURNAL OF FAMILY HISTORY}

筑 35

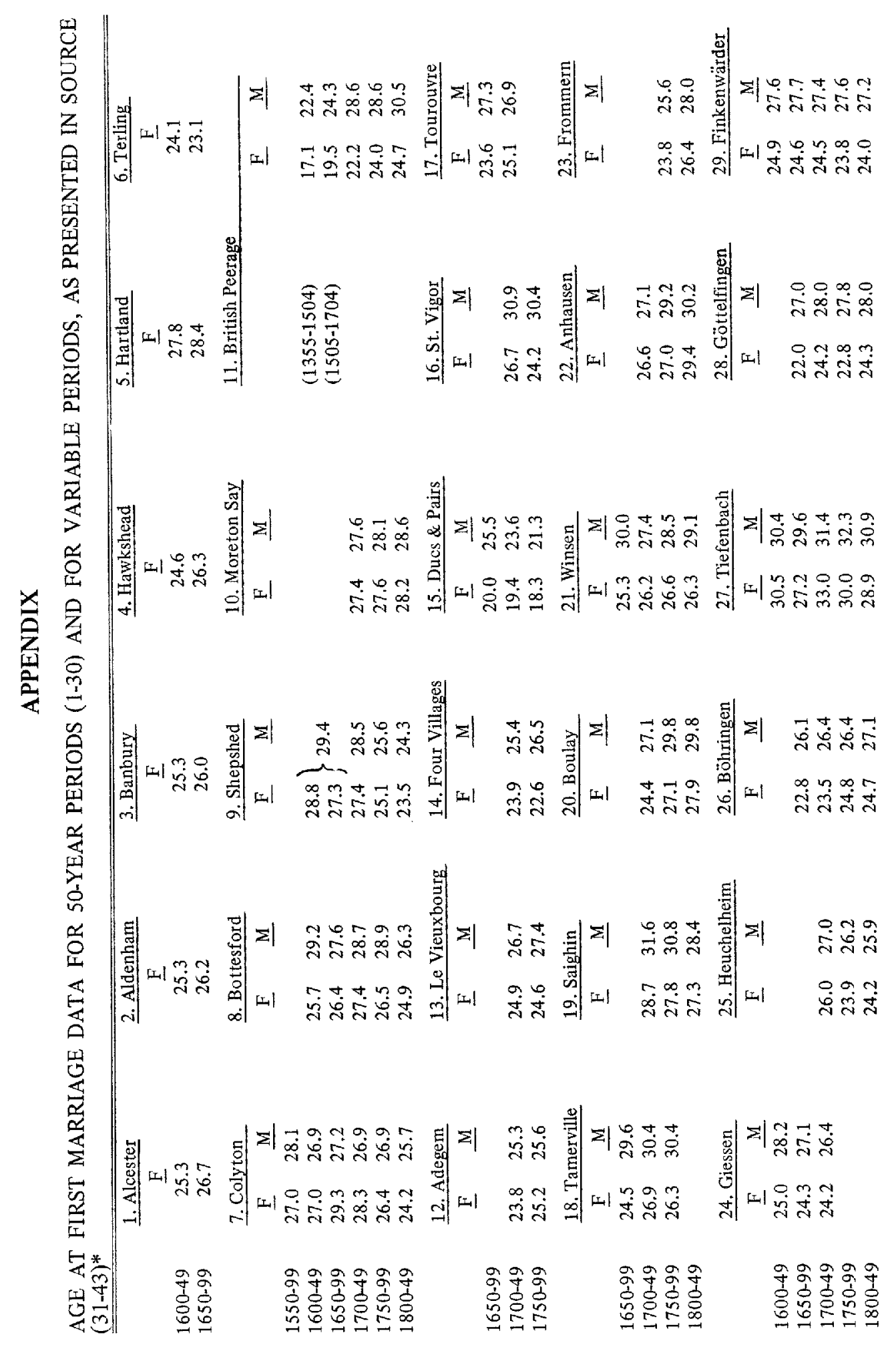




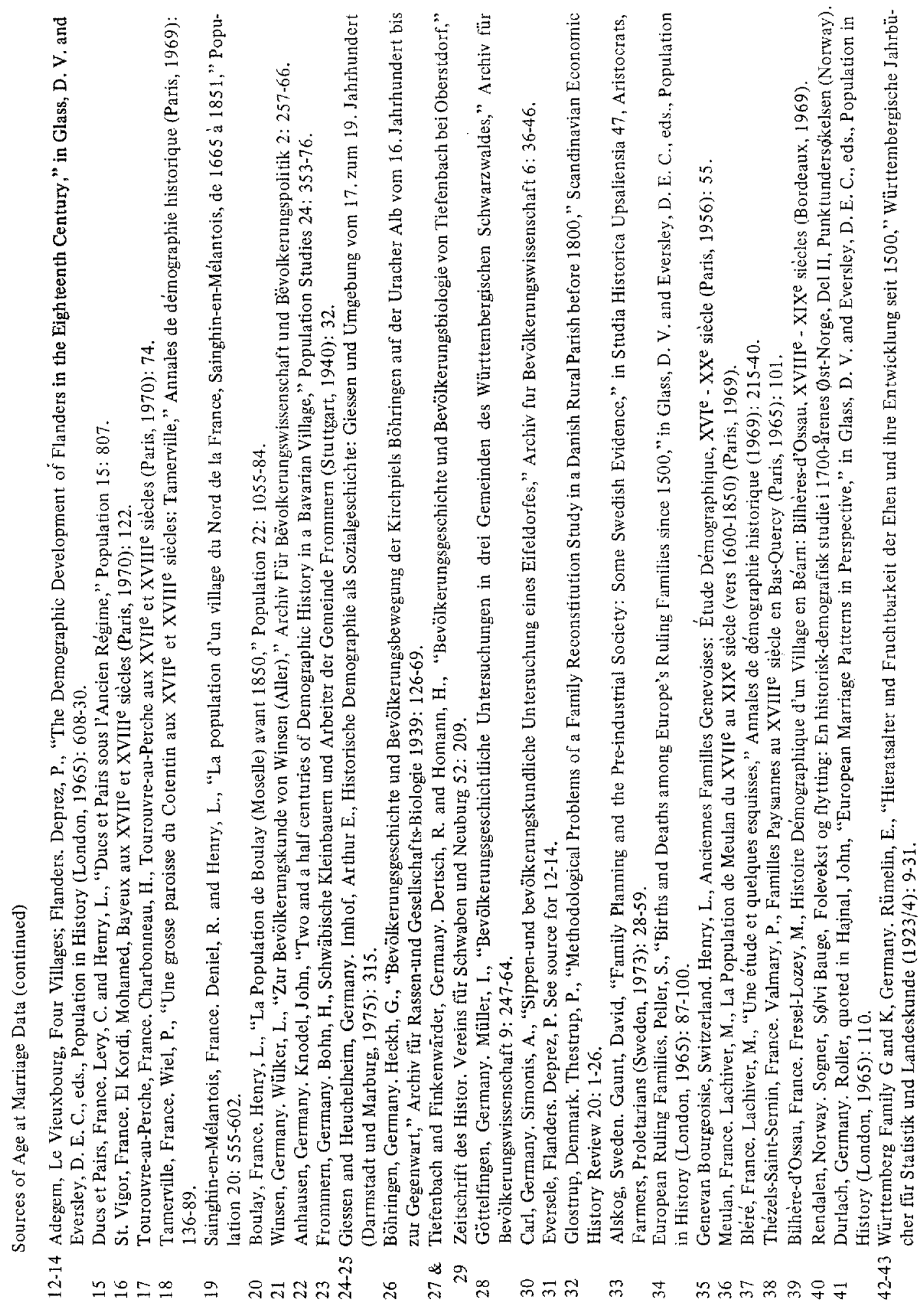

